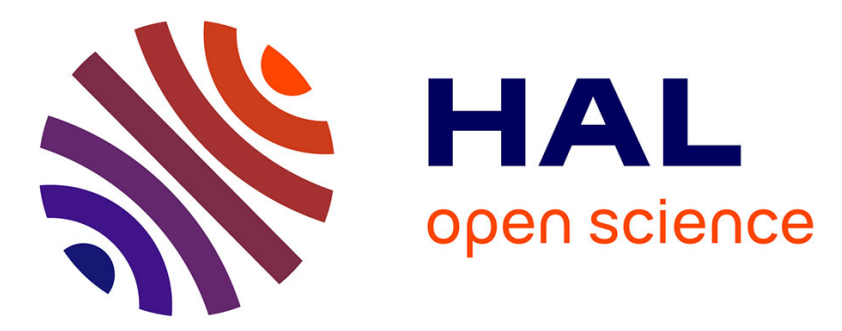

\title{
Molecular investigation of transplacental and vector-borne transmission of bovine haemoplasmas
}

\author{
S. Hornok, A. Micsutka, M.L. Meli, H. Lutz, R. Hofmann-Lehmann
}

\section{To cite this version:}

S. Hornok, A. Micsutka, M.L. Meli, H. Lutz, R. Hofmann-Lehmann. Molecular investigation of transplacental and vector-borne transmission of bovine haemoplasmas. Veterinary Microbiology, 2011, 152 (3-4), pp.411. 10.1016/j.vetmic.2011.04.031 . hal-00724197

\section{HAL Id: hal-00724197 https://hal.science/hal-00724197}

Submitted on 20 Aug 2012

HAL is a multi-disciplinary open access archive for the deposit and dissemination of scientific research documents, whether they are published or not. The documents may come from teaching and research institutions in France or abroad, or from public or private research centers.
L'archive ouverte pluridisciplinaire HAL, est destinée au dépôt et à la diffusion de documents scientifiques de niveau recherche, publiés ou non, émanant des établissements d'enseignement et de recherche français ou étrangers, des laboratoires publics ou privés. 


\section{Accepted Manuscript}

Title: Molecular investigation of transplacental and vector-borne transmission of bovine haemoplasmas

Authors: S. Hornok, A. Micsutka, M.L. Meli, H. Lutz, R. Hofmann-Lehmann

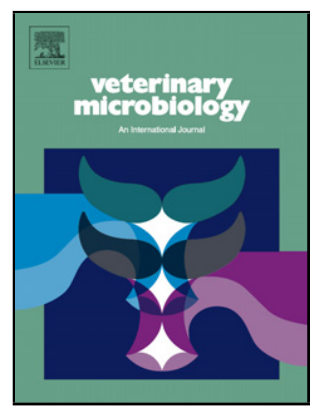

PII: S0378-1135(11)00261-6

DOI: doi:10.1016/j.vetmic.2011.04.031

Reference: VETMIC 5294

To appear in: VETMIC

Received date: 17-1-2011

Revised date: $14-4-2011$

Accepted date: $19-4-2011$

Please cite this article as: Hornok, S., Micsutka, A., Meli, M.L., Lutz, H., Hofmann-Lehmann, R., Molecular investigation of transplacental and vectorborne transmission of bovine haemoplasmas, Veterinary Microbiology (2010), doi:10.1016/j.vetmic.2011.04.031

This is a PDF file of an unedited manuscript that has been accepted for publication. As a service to our customers we are providing this early version of the manuscript. The manuscript will undergo copyediting, typesetting, and review of the resulting proof before it is published in its final form. Please note that during the production process errors may be discovered which could affect the content, and all legal disclaimers that apply to the journal pertain. 

.

\title{
Molecular investigation of transplacental and vector-borne
}

\section{transmission of bovine haemoplasmas}

\author{
Hornok S. ${ }^{\mathrm{a}, *}$, Micsutka A. ${ }^{\mathrm{a}}$, Meli M. L. ${ }^{\mathrm{b}}$, Lutz H. ${ }^{\mathrm{b}}$, Hofmann-Lehmann R. ${ }^{\mathrm{b}}$
}

${ }^{\mathrm{a}}$ Department of Parasitology and Zoology, Faculty of Veterinary Science, Szent István University, István u. 2., 1078 Budapest, Hungary

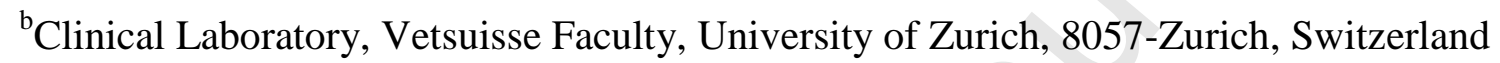

* Corresponding author. Tel.: 36-1-478-4187, Fax: 36-1-478-4193

E-mail address: Hornok.Sandor@aotk.szie.hu 3

\section{Abstract}

The present study was carried out in a herd with concurrent infections of Mycoplasma wenyonii and 'Candidatus M. haemobos', to investigate if transplacental and/or vector-borne transmission is possible for one or both bovine haemoplasma species. For this purpose blood samples were collected from 38 mother animals and their newborn calves; as well as from 17 uninseminated cows twice three months apart. In addition, 311 mosquitoes and blood-sucking flies (Diptera: Culicidae, Tabanidae, Muscidae) were cought near the animals. DNA was extracted from all samples, followed by real-time PCR analysis. In $10.5 \%$ of neonate calves, that were born to cows harbouring both haemoplasmas, M. wenyonii and/or 'Candidatus $\mathrm{M}$. haemobos' positivity was detected. Copy numbers in positive samples from cows and their 
calves indicated that - in comparison with M. wenyonii - 'Candidatus M. haemobos'bacteraemia had usually lower levels. In samples of uninseminated cows the rate of infection with the latter species decreased. These findings may explain why $M$. wenyonii was significantly more frequently detected in blood-sucking flies, than 'Candidatus M. haemobos'. In conclusion, molecular evidence is provided for the first time on the transplacental transmission of bovine haemoplasmas. Regarding their spread by blood-sucking arthropods, new potential vectors were identified, i.e. the horn fly (Haematobia irritans), the stable fly (Stomoxys calcitrans) and two species of horse flies (Tabanus bovinus, T. bromius).

\section{Keywords: Mycoplasma; haemoplasma; transplacental; vector; Diptera}

\section{Introduction}

Haemotropic mycoplasmas or haemoplasmas (formerly Haemobartonella and Eperythrozoon spp.) are Gram-negative, wall-less epierythrocytic bacteria (Neimark et al., 2001). They can cause acute or chronic disease, most notably haematological disorders in various mammals (Messick, 2004). In cattle formerly only one species, Mycoplasma (E.) wenyonii was regarded as valid, since data in the literature on the existence of other species - including $H$. bovis - are controversial (Hoelzle et al., 2010). However, based on its 16S rRNA genotype, a novel microorganism, 'Candidatus M. haemobos' was also discovered (Hofmann-Lehmann et al., 2004; Tagawa et al., 2008; Hoelzle et al, in press). These two bovine haemoplasmas have a worldwide occurrence, and were reported to elicit anaemia, oedema, reproductive problems and various other clinical signs (Smith et al., 1990; Messick, 2004; Tagawa et al., 2008; Hoelzle et al., in press). According to a recent study 'Candidatus M. haemobos' appears to be more pathogenic (Tagawa et al., 2010). 
Regarding the epidemiology of haemoplasmoses in general, routes of infection are incompletely characterised. Transplacental transmission was suggested and verified for only a few species (Berrier and Gouge, 1954; Almy et al, 2006). Although no biological vector was ever identified for haemotropic Mycoplasma spp., blood-sucking arthropods were shown to contribute to the spread of infection - most likely mechanically - in case of certain species (Daddow, 1980; Neimark et al., 2001; Messick, 2004). For bovine haemoplasmas in particular, vector competency in transmitting $M$. wenyonii was proven only for Dermacentor andersoni (Neimark and Kocan, 1997). However, D. andersoni is not indigenous outside North America, and European Dermacentor spp. collected from haemoplasma-infected cattle were found negative for these disease agents (Hornok et al., in press). Similarly, vector potential in spreading $M$. wenyonii was suggested for Haematopinus lice (Hofmann-Lehmann et al., 2004), but $H$. eurysternus removed from cattle in several herds of a haemoplasmaendemic region were found all negative for this species (Hornok et al., 2010). At the same time there is no report on the analysis of vector-borne transmission in case of 'Candidatus $\mathrm{M}$. haemobos'.

In order to compensate for such lack of data or inconsistency in the literature, the present study was undertaken to clarify if transplacental and/or vector-borne transmission is possible for one or both bovine haemoplasma species.

\section{Materials and Methods}

\subsection{Sample collection}

Sampling was performed in a privately owned herd of 100 limousine beef cattle, in the first half of 2010. These animals were kept extensively in northern Hungary, where high 
prevalence of bovine haemoplasmosis was diagnosed (Hornok et al., in press). From 38 pregnant cows housed separately EDTA-anticoagulated blood samples were collected at around delivery. Precolostral blood sample from their calves was taken shortly after birth. From a group of further 17 uninseminated cows (recently imported from another part of the country) two blood samples were obtained three months apart. In this way altogether 110 blood samples were included in the study. Blood sucking insects (Diptera: Culicidae, Tabanidae, Muscidae) were collected near the animals by fine mesh. The species or genera for vector-candidates were identified according to standard keys, and all specimens were stored in $70 \%$ ethanol until evaluation.

\subsection{DNA extraction and molecular methods}

DNA was extracted with the QIAamp DNA mini kit (QIAGEN, Hilden, Germany) following the manufacturer's instructions. From blood samples $200 \mu \mathrm{l}$ was used for the extractions. Regarding potential vectors, smaller species were pooled, whereas larger ones were processed individually (Table 2). All insects were washed sequentially in detergent containing water, in tapwater and in distilled water. Air-dried specimens were minced with pointed scissors at the bottom of Eppendorf-tubes in $100 \mu \mathrm{l}$ of phosphate-buffered saline (PBS). For DNA extraction from these samples an overnight digestion step (incubation at $56{ }^{\circ} \mathrm{C}$ for at least 8 hours) with tissue lysis buffer and Proteinase-K (QIAGEN, Hilden, Germany) was also included.

The presence of amplifiable DNA was tested by using an 18S rRNA gene TaqMan real-time PCR (Applied Biosystems, Rotkreuz, Switzerland) as described previously (Boretti et al., 2009). In case of high CT values (inhibition) another 1:10 dilution was prepared and analysed further. Real-time PCR evaluation of samples for bovine haemoplasmas was done in two species-specific assays based on the amplification of the 16S rRNA gene (Meli et al., 
101 2010), with different sets of primers and probes for $M$. wenyonii and 'Candidatus M.

102 haemobos'. Based on the lack of false positives during their preliminary evaluation, both

103 assays had $100 \%$ specificity, and they were sensitive enough to detect one copy of gene per

104 reaction (Meli et al., 2010). For quantitation by standards, tenfold serial dilutions of cloned

105 plasmid DNA with known copy number were used in each test of the present study.

106

107

\subsection{Statistical analysis}

108

109 For rates of PCR-positivity exact confidence intervals (CI) at the level of $95 \%$ were calculated

110 according to Sterne's method (Reiczigel, 2003). Prevalences were compared by using Fisher's

111 exact test, and mean values by student's $t$-test. Differences were regarded significant when $\mathrm{P}<$ 1120.05.

\section{Results}

3.1. Transplacental transmission

All 38 mother cows were PCR positive to M. wenyonii and/or 'Candidatus M. haemobos'.

Neonatal PCR positivity was detected in $10.5 \%$ of calves (4 out of 38). Despite their mother's dual infections, two of the calves were positive only for 'Candidatus M. haemobos', one only

121 for $M$. wenyonii, and another for both haemoplasmas. In samples of newborn calves the mean copy number (i.e. bacterial load) of $M$. wenyonii was higher, than of 'Candidatus $\mathrm{M}$. haemobos' (Table 1). Three of the four PCR-positive calves were males. 

significant difference between the mean copy number in samples of mother animals with a PCR-negative or with PCR-positve calf, neither for 'Candidatus M. haemobos' nor for $M$. wenyonii (data not shown). However, taking together all infected and inseminated cows, the mean copy number was significantly $(\mathrm{P}=0.015)$ higher for $M$. wenyonii-positive samples, than in case of 'Candidatus M. haemobos'-positive ones (Table 1).

\subsection{Persistance of bacteraemia}

Among uninseminated cows sampled three months apart, the rate of PCR positivity for $M$. wenyonii increased from $94 \%$ (CI: $71.3 \%-99.9 \%$ ) to $100 \%$ (Table 1 ). On the contrary, the prevalence of 'Candidatus M. haemobos'-infection decreased from $71 \%$ (CI: $44 \%-89.7 \%$ ) to 47\% (CI: 23\%-72.2\%), since four previously PCR-negative cows became PCR-positive, but detectable level of infection disappeared from eight formerly PCR-positive cows. Clearance of the latter haemoplasma from the peripheral blood was not related to the age of relevant animals (data not shown). The mean copy number (reflecting bacterial load) was higher for M. wenyonii, than for 'Candidatus M. haemobos' on both sampling occasions (Table 1).

\subsection{Occurrence in potential vectors}

Muscoid flies (Haematobia irritans and Stomoxys calcitrans), mosquitoes (Aedes/Culex spp.) and horse flies (Haematopota pluvialis and two Tabanus spp.) were caught near the animals. Results of vector analysis are shown in Table 2. Accordingly, at least four species of dipterans may be potentially involved in the transmission of bovine haemoplasmas. Altogether, $M$. wenyonii was significantly more frequently found in blood-sucking insects, than 'Candidatus

M. haemobos' $(\mathrm{P}=0.022)$. 


\section{Discussion}

154 This is the first report of transplacental infection in case of bovine haemoplasmas and the first molecular confirmation of their presence in blood-sucking dipterans (for 'Candidatus M. haemobos' in any potential vector).

In the present study neonatal PCR-positivity of calves to bovine haemoplasmas should have been a consequence of transplacental infection of the fetus, since other post-parturient routes (including colostral/galactogenic, vector-borne infection) can be discounted. Vertical (between-generation) transmission was suggested and proven for only very few other

161 haemotropic Mycoplasma spp., with some controversy in the literature. The present results also raise the possibility that intrauterine infection may be influenced by the genotype, since two of the species (M. haemosuis and M. haemolamae) for which this route was verified

164 (Berrier and Gouge, 1954; Almy et al, 2006) cluster together with M. wenyonii based on 16S rRNA phylogeny (Messick, 2004). In this study the manifestation of transplacental infection apparently did not depend on bacterial load - as reflected by copy numbers - and age of

167 mother cows. Moreover, the sex of the fetus (three males, one female) seemed not to have 168 played a role; however, these numbers were too small to draw any final conclusions. In a previous work applying the same quantitative PCR the bacterial loads of the two

170 bovine haemoplasma species were not compared (Meli et al., 2010). In the present study 171 relative to 'Candidatus $\mathrm{M}$. haemobos' - M. wenyonii-infection was accompanied by higher 172 levels (loads) of bacteraemia in calves, as well as in mother- and uninseminated cows. Among 173 the latter a decreasing prevalence of 'Candidatus M. haemobos'-positivity was also noted, as 174 contrasted to that of $M$. wenyonii. However, data on the persistance of bacteraemia in this case 
are limited to only two samplings, therefore they should not be interpreted as if obtained from

176 permanent monitoring.

Vector species evaluated in the present study were shown to be capable mechanical transmitters of other intra- or epierythrocytic bacteria (Foil, 1989; Prullage et al., 1993) except for Haematobia irritans. Consequently, to the best of our knowledge this is the first molecular detection of any haemotropic bacteria in the latter species. PCR-positivity for $M$. wenyonii and 'Candidatus M. haemobos' was demonstrated in small size muscoid flies as well as large horse flies. This may indicate that the amount of ingested blood may have been enough in both cases for mechanical transmission, taking into account that one infected red blood cell is sufficient to inoculate M. ovis (Mason and Statham, 1991). By contrast, in another study (Hornok et al., in press), all evaluated hard ticks that recently sucked blood on haemoplasmainfected cattle turned out to be PCR-negative and therefore are regarded as unlikely vectors.

On the other hand, negative PCR results of the horse fly Haematopota pluvialis, and of mosquitoes in the present study does not exclude a vector role for the relevant species in the epidemiology of bovine haemoplasmoses, and may be solely attributable to the low number of analysed pools. For instance, recently in another study one pool of mosquitoes was found (with similarly sensitive methods) to carry $M$. wenyonii (Lin et al., 2009).

Regarding the comparative occurrence of bovine haemoplasmas in blood-sucking dipterans, $M$. wenyonii predominated in the PCR-positive samples, suggesting that it may be more effectively transferred (at least mechanically) to new susceptible hosts, than 'Candidatus M. haemobos'. This may also be related to a more persistent and/or higher level bacteraemia in case of the former species, as concluded from the results above, rendering it more available for potential blood-sucking vectors.

In summary, transplacental infection and vector-borne transmission may contribute to the spread of both bovine haemoplasmas as demonstrated for the first time. However, 
detection of bacterial DNA in blood-sucking insects may only indicate a potential to carry

201

202

203

204

205

206

207

208

209

210

211

212

213

214

215

216

217

218

219

220

221

222

223

over the relevant disease agents mechanically. Since the actual vector competency of flies evaluated in the present study is unknown, and in general, the biological vector(s) of any haemotropic Mycoplasma spp. remain to be identified (if they exists at all), further studies are encouraged to clarify these aspects in the epidemiology of haemoplasmoses.

\section{Acknowledgements}

Molecular biology work was partially performed using the logistics of the Center for Clinical Studies at the Vetsuisse Faculty of the University of Zurich. Sándor Hornok is supported by the Bolyai János scholarship of the Hungarian Academy of Sciences.

\section{References}

Almy, F.S., Ladd, S.M., Sponenberg, D.P., Crisman, M.V., Messick, J.B., 2006. Mycoplasma haemolamae infection in a 4-day-old cria: support for in utero transmission by use of a polymerase chain reaction assay. Can. Vet. J. 47, 229-233.

Berrier, H.H., Gouge, R.E., 1954. Eperythrozoonosis transmitted in utero from carrier sows their pigs. J. Amer. Vet. Med. Assoc. 124, 98-100.

Boretti, F.S., Perreten, A., Meli, M.L., Cattori, V., Willi, B., Wengi, N., Hornok, S., Honegger, H., Hegglin, D., Woelfel, R., Reusch, C.E., Lutz, H., Hofmann-Lehmann, R., 2009. Molecular Investigations of Rickettsia helvetica infection in dogs, foxes, humans, and Ixodes ticks. Appl. Environ. Microbiol. 75, 3230-3237. 
226 Daddow, K.N., 1980. Culex annulirostris as a vector of Eperythrozoon ovis infection in 227 sheep. Vet. Parasitol. 7, 313-317.

229 Foil, L.D., 1989. Tabanids as vectors of disease agents. Parasitol. Today 5, 88-96.

231 Hoelzle, K., Hofmann-Lehmann, R., Hoelzle, L.E., 2010. 'Candidatus Mycoplasma haemobos', a new bovine haemotrophic Mycoplasma species? Vet. Microbiol. 144, 525-526.

Hoelzle, K., Winkler, M., Kramer, M.M., Wittenbrink, M.M., Dieckmann, S.M., Hoelzle, press.

Hofmann-Lehmann, R., Meli, M.L., Dreher, U.M., Gönczi, E., Deplazes, P., Braun, U.,

239 Engels, M., Schüpbach, J., Jörger, K., Thoma, R., Griot, C., Stärk, K.D., Willi, B., Schmidt, 240 J., Kocan, K.M., Lutz, H., 2004. Concurrent infections with vector-borne pathogens 241 associated with fatal hemolytic anemia in a cattle herd in Switzerland. J. Clin. Microbiol. 42, $242 \quad 3775-3780$.

244 Hornok, S., Hofmann-Lehmann, R., Fernández de Mera, I.G., Meli, M.L., Elek, V., Hajtós, I., 245 Répási, A., Gönczi, E., Tánczos, B., Farkas, R., Lutz, H., de la Fuente, J., 2010. Survey on 246 blood-sucking lice (Phthiraptera: Anoplura) of ruminants and pigs with molecular detection of 247 Anaplasma and Rickettsia spp. Vet. Parasitol. 174, 335-338. 
Hornok, S., Micsutka, A., Fernández de Mera, I.G., Meli, M.L., Gönczi, E., Tánczos, B.,

250 Mangold, A.J., Farkas, R., Lutz, H., Hofmann-Lehmann, R., de la Fuente, J. Fatal bovine anaplasmosis in a herd with new genotypes of Anaplasma marginale, A. ovis and concurrent haemoplasmosis. Res. Vet. Sci., in press.

Lin, P.C., Hawley, J.R., Bolling, B.G., Eisen, L.M., Lappin, M.R., 2009. Prevalence of haemoplasma DNA in field-caught mosquitoes in Colorado. J. Vet. Intern. Med. 23, 718.

Mason, R.W., Statham, P., 1991. The determination of the level of Eperythrozoon ovis parasitaemia in chronically infected sheep and its significance to the spread of infection. Aust. Vet. J. 68, 115-116.

Meli, M.L, Willi, B., Dreher, U.M., Cattori, V., Knubben-Schweizer, G., Nuss, K., Braun, U.,

Lutz, H., Hofmann-Lehmann, R., 2010. Identification, molecular characterization and occurrence of two bovine hemoplasma species in Swiss cattle and development of real-time TaqMan quantitative PCR assays for diagnosis of bovine hemoplasma infections. J. Clin. Microbiol. 48, 3563-3568.

Messick, J.B., 2004. Hemotrophic mycoplasmas (hemoplasmas): a review and new insights into pathogenic potential. Vet. Clin. Pathol. 33, 2-13.

Neimark, H., Johansson, K.-E., Rikihisa, Y., Tully, J.G., 2001. Proposal to transfer some

271 members of the genera Haemobartonella and Eperythrozoon to the genus Mycoplasma with 
273 haemomuris', ' Candidatus Mycoplasma haemosuis' and 'Candidatus Mycoplasma

274 wenyonii’. Int. J. Syst. Evol. Micr. 51, 891-899.

275

276 Neimark, H., Kocan, K.M., 1997. The cell wall-less rickettsia Eperythrozoon wenyonii is a 277 Mycoplasma. FEMS Microbiol. Lett. 156, 287-291.

278

279 Prullage, J.B., Williams, R.E., Gaafar, S.M., 1993. On the transmissibility of Eperythrozoon 280 suis by Stomoxys calcitrans and Aedes aegypti. Vet. Parasitol. 50, 125-135.

281

282 Reiczigel, J. 2003. Confidence intervals for the binomial parameter: some new considerations.

283 Stat. Med. 22, 611-621.

284

285 Smith, J.A., Thrall, M.A., Smith, J.L., Salman, M.D., Ching, S.V., Collins, J.K., 1990.

286 Eperythrozoon wenyonii infection in dairy cattle. J. Am. Vet. Med. Assoc. 196, 1244-1250.

287

288 Tagawa, M., Matsumoto, K., Inokuma, H., 2008. Molecular detection of Mycoplasma

289 wenyonii and 'Candidatus Mycoplasma haemobos' in cattle in Hokkaido, Japan. Vet.

290 Microbiol. 132, 177-180.

291

292 Tagawa, M., Matsumoto, K., Yokoyama, N., Inokuma, H., 2010. Comparison of the effect of

293 two hemoplasma species on hematological parameters in cattle.

294 J. Vet. Med. Sci. 72, 113-115. 
Table 1.

2 Results of bovine haemoplasma-specific real-time PCRs with samples of cows and calves.

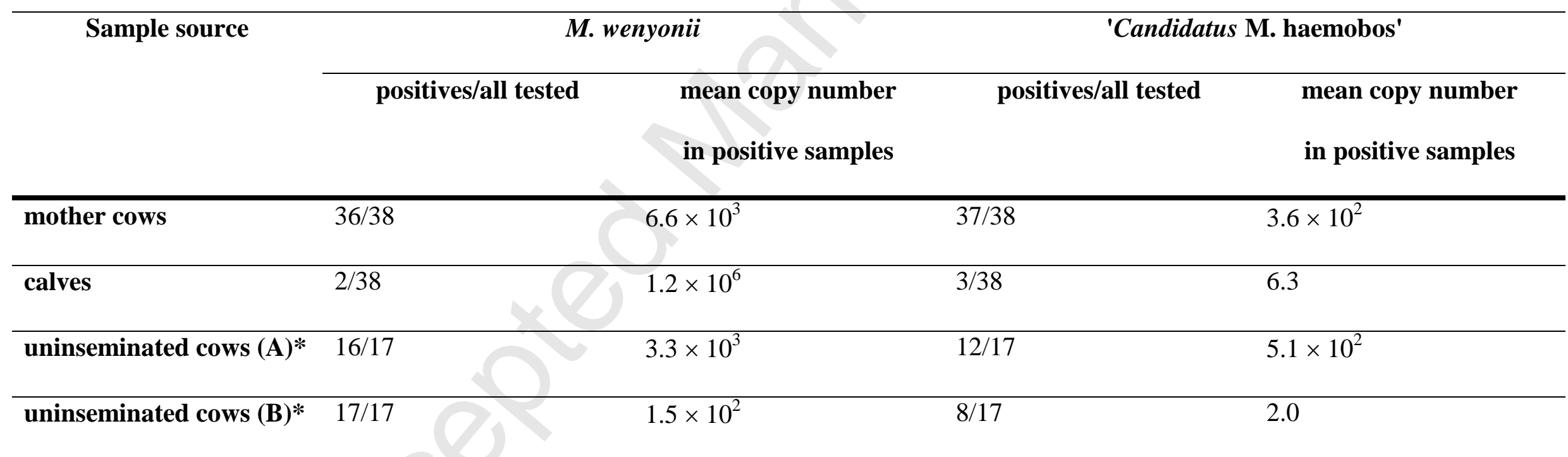

4

$5 * \mathrm{~A}$ and $\mathrm{B}$ refer to consequent samplings three months apart 
Table 2.

2 Results of bovine haemoplasma-specific real-time PCRs with blood-sucking insects analysed in pools or individually.

\begin{tabular}{|c|c|c|c|c|c|}
\hline \multirow[t]{2}{*}{ Dipteran species } & \multirow{2}{*}{$\begin{array}{c}\text { No. of } \\
\text { specimens } \\
\text { in one sample }\end{array}$} & \multicolumn{2}{|c|}{ M. wenyonii } & \multicolumn{2}{|c|}{ 'Candidatus M. haemobos' } \\
\hline & & positives/all tested & $\begin{array}{c}\text { mean copy number in } \\
\text { positive samples }\end{array}$ & positives/all tested & $\begin{array}{l}\text { mean copy number } \\
\text { in positive samples }\end{array}$ \\
\hline Haematobia irritans & 8 & $1 / 20$ & $1.9 \times 10^{2}$ & $2 / 20$ & 1.0 \\
\hline Stomoxys calcitrans & 4 & $6 / 20$ & $1.0 \times 10^{2}$ & $1 / 20$ & 1.0 \\
\hline Aedes/Culex spp.* & 8 & $0 / 5$ & 0 & $0 / 5$ & 0 \\
\hline Haematopota pluvialis* & 1 & $0 / 7$ & 0 & $0 / 7$ & 0 \\
\hline Tabanus bromius* & 1 & $2 / 8$ & $6.1 \times 10$ & $0 / 8$ & 0 \\
\hline T. bovinus* & 1 & $5 / 16$ & $3.2 \times 10$ & $1 / 16$ & $1.3 \times 10$ \\
\hline
\end{tabular}

4

$5 \quad$ *only females suck blood and were included

6 